Research Article

\title{
Awareness Assessment regarding COVID-19 among Population - A Cross-Sectional Online Study
}

\author{
Hardeep Kaur', Satinder Kaur ${ }^{2}$, Pushpa $^{3}$, Shatrughan Pareek ${ }^{4}$ \\ ${ }^{1}$ Professor and HOD, Department of Community Health Nursing, University College of Nursing, BFUHS, Faridkot, Punjab, India. \\ 2,3 Demonstrator, University College of Nursing, BFUHS, Faridkot, Punjab, India. \\ ${ }^{4}$ Nursing Superintendent, Indian Railway Health Services, Bikaner, Rajasthan, India.
}

DOI: https://doi.org/10.24321/2455.9318.202013

\section{I $\quad \mathbf{N} \quad \mathbf{F} \quad \mathbf{O}$}

\section{Corresponding Author:}

Shatrughan Pareek, Indian Railway Health Services, Bikaner, Rajasthan, India.

E-mail Id:

shatrughan.pareek@gmail.com

Orcid Id:

https://orcid.org/0000-0003-3585-1617

How to cite this article:

Kaur H, Kaur S, Pushpa, Pareek S. Awareness Assessment regarding COVID-19 among Population - A Cross-Sectional Online Study. Int J Nurs Midwif Res 2020; 7(2): 16-20.

Date of Submission: 2020-00-oo

Date of Acceptance: 2020-00-00

\section{$\begin{array}{llllllll}\mathbf{A} & \mathbf{B} & \mathbf{S} & \mathbf{T} & \mathbf{R} & \mathbf{A} & \mathbf{C} & \mathbf{T}\end{array}$}

Background and Objective: Corona virus disease (COVID-19) is a very contagious disease. The study was conducted with aim to assess the awareness towards Corona virus disease among the population. Awareness towards the disease is important for prevention and control.

Methodology: The research design was descriptive cross-sectional design. The study was conducted online in India due to COVID-19 crisis and lockdown. A structured awareness questionnaire was distributed to subjects by using social media platform. The questionnaire was based on information by the WHO. In present study, 585 subjects were included in the study by non-randomized snowball sampling technique.

Result: In the present study, almost two third i.e. $66.2 \%$ of the respondents were females while; one third (33.8\%) were males. Majority of the subjects (46\%) learned about COVID-19 from social media. Awareness towards spread of disease and supportive treatment were $92.2 \%$ and $74 \%$ respectively. Additionally, majority i.e. $97 \%$ respondents knew the measures to be done if COVID-19 symptom occurs. In terms of affected by COVID-19, more than half i.e. $55.9 \%$ stated that all age groups are equally at risk followed by $39.7 \%$ disagreed with this statement, while $4.4 \%$ had no idea. Furthermore, towards COVID-19 management, $84.3 \%$ responses were correct. The overall awareness regarding COVID-19 was $74.2 \%$.

Conclusion: Upon understanding the percentage of people not aware about the age groups this virus will be affecting, keeping in mind good amount of knowledge amongst individuals about maintaining hygiene and social distancing, this survey would help the health care workers to create awareness regarding the effect of this virus on different age groups to help prevent carelessness amongst youth in following the regime. Furthermore, awareness among population towards the disease is crucial to minimize morbidity and mortality due to the disease.

Keywords: COVID-19, Awareness, Assessment, Population, India, Prevention 


\section{Introduction}

The World Health Organization (WHO) used the term novel corona virus 2019 for the virus that affects lower respiratory tract of patients with pneumonia. Corona virus infection is highly contagious diseases and transmitted transmission of COVID 19 viruses are from person-to-person and similar to seasonal influenza and may cause the same symptoms. The incubation period of COVID-19 is approximately 2-14 days. ${ }^{1-3}$ Bats are considered as natural hosts of these viruses yet several other species of animals are also known to be a source such as camels and civet cats. ${ }^{4}$ There is no vaccine and no specific treatment for this virus so far and because it is a new virus, nobody has prior immunity which in theory means that the entire human population is potentially susceptible to COVID-19 infection..$^{5}$ There is not enough epidemiological at this time to determine how easily and sustainably this virus spreads between people, but it is currently estimated that, on average, one infected person will infect many persons. The virus seems to be transmitted mainly via respiratory droplets that people sneeze, cough, or exhale. The virus can also survive for several hours on surfaces such as tables and door handles. ${ }^{6}$ The symptoms are fever, cough, difficulty breathing, muscle pain and tiredness. More serious cases develop severe pneumonia, acute respiratory distress syndrome, sepsis and septic shock that can lead to death. ${ }^{7}$ People who are at greater risk of developing severe symptoms are: elderly people and those with health disorders such as hypertension, diabetes, cardiovascular disease, chronic respiratory disease and cancer. Relatively rare and mild infection has been seen that in children. ${ }^{8,9}$

\section{Need of the Study}

As there is no specific treatment for the pandemic, so healthcare providers treat the patients on the basis of clinical symptoms (e.g. fever, difficulty breathing). Patients with symptoms are effectively given supportive care (e.g. fluid management, oxygen therapy, etc.). ${ }^{10}$ Maheshwari et al. stated that people's observance of the prevention measures is essential for controlling the spread of COVID-19, which is affected by their knowledge, attitudes, and practices (KAP) towards COVID-19. ${ }^{11}$

The aim of this study is to assess the awareness among Indian people about COVID-19 outbreak and steps to be taken for its prevention. It is important to assess the knowledge, attitude and behavior of the public towards important and prevalent infectious diseases. Such information provides baseline data for the prevention and control of these diseases through estimation of the impact of previous preventions made by the government and guiding the need for further interventions.

\section{Methodology}

This cross-sectional online survey employed a convenient snowball sampling technique. Using Google forms, a questionnaire gathering demographic data and awareness with respect to COVID-19 was prepared and distributed via WhatSapp and e-mail in post-lockdown period, when there was sharp increase in COVID-19 cases. First question was pertaining to taking consent i.e. whether the participant is willing to participate. Thus, the participation was voluntary. People with Whatapp and e-mail, the ability to understand and read English, residing in India and above 18 years of age were included in the study. The survey rendered 585 responses. This survey, which was conducted, contained 10 questions with multiple choice questions. All the individuals who answered the survey were informed about the confidentiality of their response and were also informed about the purpose of conducting this survey. Each and every individual of India of all age groups were included in this survey. The evaluation of this survey was done electronically using the inter phase provided by the common survey software conducting site available on internet.

\section{Result}

Table 1, depicts frequency and percentage distribution of demographic characteristics of the respondents. As per age, almost half, $53.3 \%$ of respondents were in the age group of 18 to 25 years, followed by $15 \%$ in 41 to 48 years. Almost two third i.e. $66.2 \%$ of the respondents were females while; one third (33.8\%) were males. As per educational status, maximum $68.4 \%$ were graduate and above followed by $26.4 \%, 12$ th standard pass. In occupation, almost half of respondents i.e. $49.9 \%$ were students, followed by $24.8 \%$, were government servant. Maximum participants (58.6\%) were unmarried and $40.5 \%$ were married. As per type of family more than two third i.e. $68.5 \%$ belonged to nuclear families and $31.5 \%$ belonged to joint family. Figure- 1 showed that, majority i.e. 46\% learned about COVID-19 from social media, followed by $32 \%$ from news feeds and $19 \%$ from health professionals. As per table-2, majority of respondents $(80.5 \%)$ were agreed that COVID-19 is contagious, while, $16.2 \%$ had no idea regarding contagiousness of the disease. Only $42 \%$ of respondents know about right incubation period of COVID-19. Approximately two third of respondents knows that COVID-19 is spread by bats and pangolins. $3.9 \%$ reported that disease is spread by camels, while $31.5 \%$ had no idea regarding the spread of the disease. Furthermore, nearly three fourth of the respondents knew about the sign and symptoms of COVID-19. Maximum, 74\% respondents knew that COVID-19 patient is given supportive treatment. Additionally, majority i.e. $97 \%$ respondents knew the measures to be done if COVID-19 symptom occurs. Mostly, $92.2 \%$ knows that COVID-19 is spread through 
air transmission. In terms of affected by COVID-19, more than half i.e. 55.9\% stated that all age groups are equally at risk followed by $39.7 \%$ disagreed with this statement, while $4.4 \%$ had no idea. Regarding COVID-19 management, $84.3 \%$ given right response. The overall awareness regarding COVID-19 was $74.2 \%$.

Table I.Frequency and percentage distribution of demographic characteristics of respondents

$(\mathrm{N}=585)$

\begin{tabular}{|c|c|c|c|}
\hline S. & \multicolumn{2}{|c|}{ Demographic characteristics } & n (\%) \\
\hline \multirow{5}{*}{1.} & \multirow{5}{*}{ Age (Years) } & $18-25$ & $312(53.3)$ \\
\hline & & $26-32$ & $57(9.7)$ \\
\hline & & $33-40$ & $60(10.3)$ \\
\hline & & $41-48$ & $88(15)$ \\
\hline & & Above 48 & 68 (11.6) \\
\hline \multirow{2}{*}{2.} & \multirow{2}{*}{ Gender } & Male & $198(33.8)$ \\
\hline & & Female & $387(66.2)$ \\
\hline \multirow{5}{*}{3.} & \multirow{5}{*}{$\begin{array}{c}\text { Educational } \\
\text { Status }\end{array}$} & Below 10th & $13(2.2)$ \\
\hline & & 10th Standard & $19(3.2)$ \\
\hline & & 12th Standard & $153(26.4)$ \\
\hline & & $\begin{array}{c}\text { Graduate and } \\
\text { above }\end{array}$ & $400(68.4)$ \\
\hline & & None & $17(2.9)$ \\
\hline \multirow{6}{*}{4.} & \multirow{6}{*}{ Occupation } & Student & $292(49.9)$ \\
\hline & & Housewife & $38(6.5)$ \\
\hline & & Govt. Service & $145(24.8)$ \\
\hline & & Pvt. Service & $53(9.1)$ \\
\hline & & Business & $14(2.4)$ \\
\hline & & Other & $26(4.4)$ \\
\hline \multirow{4}{*}{5.} & \multirow{4}{*}{$\begin{array}{l}\text { Marital } \\
\text { Status }\end{array}$} & Unmarried & $343(58.6)$ \\
\hline & & Married & $237(40.5)$ \\
\hline & & Widow/Widower & $0(00)$ \\
\hline & & $\begin{array}{l}\text { Divorced/ } \\
\text { Separated }\end{array}$ & $5(0.9)$ \\
\hline \multirow{2}{*}{6.} & \multirow{2}{*}{$\begin{array}{l}\text { Type of } \\
\text { family }\end{array}$} & Nuclear & $401(68.5)$ \\
\hline & & Joint & $184(31.5)$ \\
\hline
\end{tabular}

Table 2.Item wise distribution of responses regarding awareness

$(\mathrm{N}=585)$

\begin{tabular}{|c|c|c|}
\hline Item No. & Item & $\begin{array}{c}\text { Correct } \\
\text { response N } \\
\text { (\%) }\end{array}$ \\
\hline 1. & $\begin{array}{c}\text { Is this COVID-19 disease } \\
\text { Contagious? }\end{array}$ & $471(80.5 \%)$ \\
\hline
\end{tabular}

\begin{tabular}{|c|c|c|}
\hline 2. & $\begin{array}{c}\text { What is the incubation } \\
\text { period (infected person } \\
\text { can transmit infection to } \\
\text { healthy persons) COVID-19? }\end{array}$ & $245(42 \%)$ \\
\hline 3. & $\begin{array}{c}\text { From where did COVID-19 } \\
\text { spread? }\end{array}$ & 376 (64.3\%) \\
\hline 4. & $\begin{array}{l}\text { What are the symptoms of } \\
\text { COVID-19? }\end{array}$ & $454(77.6 \%)$ \\
\hline 5. & $\begin{array}{l}\text { What is the treatment of } \\
\text { COVID-19? }\end{array}$ & $433(74 \%)$ \\
\hline 6. & $\begin{array}{c}\text { What to do for prevention } \\
\text { of COVID-19? }\end{array}$ & 567 (97\%) \\
\hline 7. & $\begin{array}{c}\text { How does corona virus } \\
\text { spread? }\end{array}$ & $539(92.2 \%)$ \\
\hline 8. & $\begin{array}{c}\text { Are all age groups affected } \\
\text { equally? }\end{array}$ & $327(55.9 \%)$ \\
\hline 9. & $\begin{array}{c}\text { What should be done if you } \\
\text { have symptoms of COVID } \\
-19 ?\end{array}$ & 493 (84.3\%) \\
\hline $\begin{array}{c}\text { Total } \\
\text { awareness }\end{array}$ & $74.2 \%$ & \\
\hline
\end{tabular}

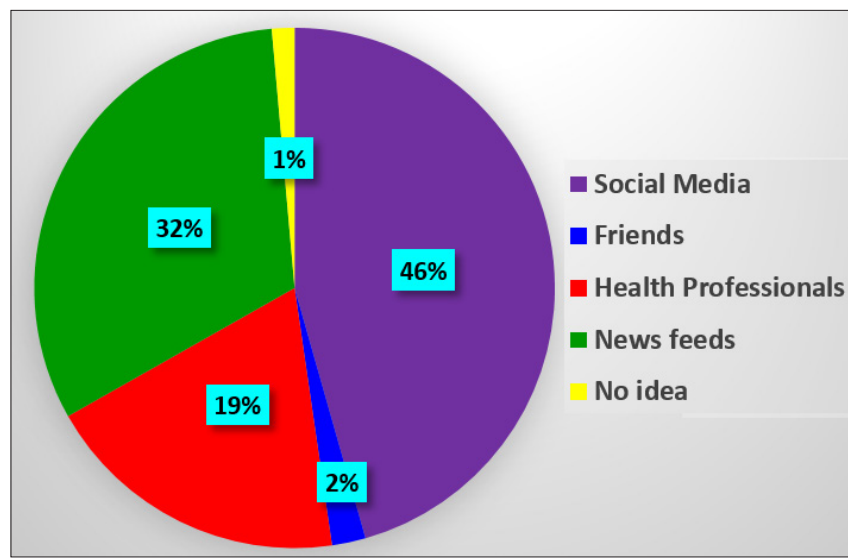

Figure I.Source of information regarding COVID-I 9 among population

\section{Discussion}

The present study was conducted with aim to assess the existing awareness among the population towards COVID-19. As per figure-1, majority i.e. 46\% learned about COVID-19 from social media, followed by $32 \%$ from news feeds and $19 \%$ from health professionals. Only $2 \%$ respondents learned from fiends, while $1 \%$ had no idea about this information. In this context, Thakur K, et al. stated that mostly participants $(64.8 \%)$ gain the information from social media. ${ }^{12}$ Singh $A K$, et al. communicated that majority of the respondents (68.3\%) got information from television. ${ }^{13}$ The present study highlighted that almost participants (97\%) know about the preventive measures of COVID-19 and $92.2 \%$ people 
know about its mode of spread. In contrast with present study, Giao $\mathrm{H}$ et al. reported that only $67.0 \%$ and $58.4 \%$ of good answers relate to the transmission by close contact with an infected person and treatment of the COVID-19 virus. ${ }^{14}$ Furthermore, a descriptive study communicated that correct response regarding transmission by close contact was (92.5\%), and treatment $(77.5 \%)$ respectively. The present study highlighted that only $42 \%$ respondents knew about incubation period of COVID-19 while, Sharma $\mathrm{M}$ et al. reported that more than $90 \%$ participants are familiar to incubation period. ${ }^{15}$

In addition, present study communicated that nearly three fourth populations has awareness regarding symptoms (77.7\%), treatment (74\%) and management (84.3\%) of COVID-19. Singh AK et al. highlighted that most of respondents $(\geq 95 \%)$ responded correctly about mode of spread and causative virus. ${ }^{13}$ The present study also stated that $92.2 \%$ subjects know about the spread of COVID-19. A cross-sectional study was conducted in South-West Saudi Arabia regarding awareness COVID-19 outbreak. The study revealed that majority of the subjects (97.7\%) mentioned that cause of COVID-19 transmission was human-to-human contact.16 Nearly similar level of awareness was reported in the present study. Furthermore, a KAP study was conducted among the Indian citizens towards COVID-19. The study concluded that participants have incomplete awareness regarding COVID-19. The present study also communicated the same findings. ${ }^{17}$ In terms of overall awareness, Singh $S$ et al. ${ }^{18}$ concluded that overall correct response rate on awareness question is $80.2 \%$ whereas, present study highlighted that overall awareness towards COVID-19 was $74.2 \%$. The present highlighted that in different areas of awareness, the correct responses were varying in the population. There is a need of further awareness towards COVID-19 disease.

\section{Conclusion}

The study communicated that people have limited awareness towards the pandemic. Sound knowledge, positive attitude and awareness are crucial to control and minimize the disease. There is a need to increase the awareness among individuals to enhance their active participation in the preventive measures with respect to the spread of the COVID-19. The society and people have to follow the guidelines of COVID-19. This should improve the adaptability of people with livelihood resilience to let them protect themselves not only from the present pandemic but also from all other unforeseen infections, and to provide care to patients. With active participation and support of the people of India, we can be able to control the spread of the disease in our country.

\section{Implication}

The study findings revealed that people have limited awareness towards COVID-19 so it is essential to enhance the knowledge of the population. This initiative will be important in declining the morbidity and mortality because of COVID-19. The present study will help government and peoples to understand and handle this COVID-19 pandemic effectively and in prevention of COVID-19, which is crucial for the awareness of society in coming time. Moreover, the study findings can be utilized by the government, health department and local authorities for implementation of various awareness programmes regarding the pandemic.

\section{Acknowledgement}

The authors would like to thank all participants who responded to the survey questionnaire for this study.

Funding: Self-financed

\section{Conflict of Interest: None}

\section{References}

1. World Health Organization. Corona virus. 2020. Available from: https://www.who.int/health-topics/ coronavirus. Accessed $8^{\text {th }}$ October 2020.

2. John Z. What next for the corona virus response? The Lancet 2020; 395(10222): 401.

3. Pareek S, Kaushik NK, Verma D et al. Assessment of knowledge and practices of urban population regarding COVID-19: a cross-sectional study in Bikaner, Rajasthan. Int J Community Med Public Health 2020; 7: 3095-9.

4. Hu B, Ge X, Lin-Fa W et al. Bat origin of human coronaviruses. Virology Journal 2015; 12: 221.

5. Vaccines and immunization. Available from: https://www.who.int/health-topics/vaccines-andimmunization. Accessed 5th October 2020.

6. Sharma SK, Mudgal SK, Panda PK et al. COVID-19: Guidance outlines on infection prevention and control for health care workers. Indian J Comm Health 2020; 32(1): 9-16.

7. Zaim S, Chong JH, Sankaranarayanan V, et al. COVID-19 and multiorgan response. Curr Probl Cardiol 2020; 45(8): 100618.

8. Petrie JR, Guzik TJ, Touyz RM. Diabetes, hypertension, and cardiovascular disease: clinical insights and vascular mechanisms. Can J Cardiol 2018; 34(5): 575-584.

9. Lu X, Xiang $\mathrm{Y}, \mathrm{Du} \mathrm{H}$ et al. SARS-CoV-2 infection in children - understanding the immune responses and controlling the pandemic. Pediatr Allergy Immunol 2020; 31: 449-453.

10. Jin $Y, C a i ~ L, C h e n g ~ Z$ et al. A rapid advice guideline for the diagnosis and treatment of 2019 novel coronavirus (2019-nCoV) infected pneumonia. Military Med Res 
2020; 7: 4.

11. Maheshwari S, Gupta PK, Sinha R et al. Knowledge, attitude, and practice towards coronavirus disease 2109 (COVID-19) among medical students: a cross-sectional study. J Acute Dis 2020; 9: 100-104.

12. Thakur K, Sheharia D, Bhardwaj $\mathrm{H}$ et al. The attitude, knowledge and degree of awareness about COVID-19 among population of Himachal Pradesh, India. Int Res J Engineering Tech 2020; 7(6): 349-354.

13. Singh AK, Agrawal B, Sharma A et al. COVID-19: assessment of knowledge and awareness in Indian society. J Public Aff 2020: e2354.

14. Giao H, Han NTN, Van Khanh T et al. Knowledge and attitude toward COVID-19 among healthcare workers at District 2 Hospital, Ho Chi Minh City. Asian Pacific J Trop Med 2020; 13: 3-5.

15. Sharma M, Poonia SK. Knowledge and attitude of healthcare personnel about COVID -19 pandemic in India - cross sectional study. World J Adv Healthcare Res 2020; 4(5): 187-192.

16. Tripathi R, Alqahtani SS, Albarraq AA et al. Awareness and preparedness of COVID-19 outbreak among healthcare workers and other residents of South-West Saudi Arabia: A cross-sectional survey. Front Public Health 2020; 8: 482.

17. Kartheek AS, Gara KH, Vanamali DR. Knowledge, attitude and practices towards COVID-19 among Indian residents during the pandemic: A cross-sectional online survey. J NTR Univ Health Sci 2020; 9: 107-115.

18. Singh S, Singh RK. Awareness, attitude and practices towards COVID-19 among people of Bihar during lockdown 1.0: a cross-sectional study. Int J Sci Healthcare Res 2020; 5(2): 432-443. 